\title{
Stability of Rosmarinic Acid in Aqueous Extracts from Different Lamiaceae Species after in vitro Digestion with Human Gastrointestinal Enzymes
}

\author{
Zoran Zorić ${ }^{1}$, Joško Markićn, Sandra Pedisić ${ }^{1}$, Viljemka Bučević-Popović ${ }^{3}$, \\ Ivana Generalić-Mekinić ${ }^{4}$, Katarina Grebenar ${ }^{4}$ and Tea Kulišić-Bilušićc* \\ ${ }^{1}$ Faculty of Food Technology and Biotechnology, Centre in Zadar, P. Kasandrića 6, HR-23000 Zadar, Croatia \\ ${ }^{2}$ University Hospital of Split, Spinčićeva 1, HR-21000 Split, Croatia \\ ${ }^{3}$ Faculty of Science, Department of Chemistry, University of Split, Teslina 12, HR-21000 Split, Croatia \\ ${ }^{4}$ Faculty of Chemistry and Technology, University of Split, Teslina 10, HR-21000 Split, Croatia
}

Received: December 16, 2014

Accepted: October 22, 2015

\begin{abstract}
Summary
The present study compares the gastrointestinal stability of rosmarinic acid in aqueous extracts of thyme, winter savory and lemon balm with the stability of pure rosmarinic acid. The stability of rosmarinic acid was detected after two-phase in vitro digestion process (gastric and duodenal) with human gastrointestinal enzymes. The concentration of rosmarinic acid in undigested and digested samples was detected using HPLC-DAD. Results showed that gastrointestinal stability of pure rosmarinic acid was significantly higher than that of rosmarinic acid from plant extracts after both gastric and intestinal phases of digestion. Among plant extracts, rosmarinic acid was the most stable in lemon balm after gastric $(14.10 \%)$ and intestinal digestion phases $(6.5 \%)$. The temperature $\left(37^{\circ} \mathrm{C}\right)$ and slightly alkaline medium ( $\mathrm{pH}=7.5)$ did not affect the stability of rosmarinic acid, while acid medium ( $\mathrm{pH}=2.5)$ significantly decreased its stability $(\geq 50 \%)$. In addition, the stability rate of rosmarinic acid is influenced by the concentration of human gastrointestinal juices.
\end{abstract}

Key words: rosmarinic acid, in vitro digestion, stability, human gastrointestinal enzymes, Lamiaceae species

\section{Introduction}

Research on biologically active compounds, such as plant phenolics, represents a big scientific challenge due to a great number of identified substances, their chemical diversity as well as their huge biological potential, important for the maintenance of healthy balance in our body. Undoubtedly, rosmarinic acid is one of the most studied phenolic compounds, exhibiting different biological activities: antioxidant, anti-inflammatory, antimutagenic, antibacterial, antiviral, cytotoxic on human breast cancer cells, neuroprotective in human neurons, and nephroprotective (1-8).
In plants, rosmarinic acid is formed from amino acids phenylalanine (caffeic acid part of rosmarinic acid) and tyrosine (3,4-dihydroxyphenyllactic acid part) (9). It was isolated for the first time from Rosmarinus officinalis and its structure was characterized as an ester of caffeic acid and 3,4-dihydroxyphenyllactic acid $(10,11)$. According to some authors $(12,13)$, rosmarinic acid cannot be used as chemotaxonomic marker for differentiation of plant families due to its occurrence in various plant families such as Lamiaceae, Boraginaceae, Blechnaceae and Asteraceae. However, Lamiaceae species such as Satureja montana L., Thymus vulgaris L. and Origanum majorana L. are known as rich sources of rosmarinic acid (14-16). 
The majority of published studies on rosmarinic acid are focused on methods of its detection in various plant extracts $(17,18)$, its seasonal variations in selected plants (19) as well as its specific biological activity in different models (cell cultures, rats, in vitro methods) $(5,8,20,21)$. Therefore, there is a lack of studies on the stability of rosmarinic acid under gastrointestinal conditions using human gastrointestinal enzymes and on the influence of plant matrix on its stability rate. In that sense, in vitro models that mimic human physiology are recognized as simple, inexpensive and reproducible tools to study digestive stability of compounds (22). In addition, in vitro digestion methods are generally based on the use of commercial digestive enzymes, while studies with human gastrointestinal enzymes are still very rare.

Thus, the aim of this study is to determine the influence of digestion phase (gastric and duodenal), temperature and $\mathrm{pH}$ on the stability of rosmarinic acid. In this study human gastrointestinal juices (gastric and duodenal) collected from healthy donors are used instead of commercial gastrointestinal enzymes. The stability rate of rosmarinic acid is measured by HPLC-DAD technique.

\section{Materials and Methods}

\section{Plant material}

Plant materials used in this study were dry leaves of Thymus vulgaris L. (thyme), Satureja montana L. (winter savory), and Origanum majorana L. (lemon balm). The above-mentioned samples are commercially available, in form of tea-like preparations, and were purchased from a local herbal pharmacy (Suban d.o.o., Strmec Samoborski, Croatia). Pretreatment of the plant material included its homogenization using high speed grinder for $1 \mathrm{~min}$.

\section{Preparation of aqueous extracts}

Pulverized plant materials ( $2.5 \mathrm{~g}$ ) were extracted with distilled water $(25 \mathrm{~mL})$. To obtain better extraction yield, instead of conventional procedure, ultrasonic bath-assisted extraction was used. Flasks with suspensions were immersed in ultrasonic water bath heated to $50{ }^{\circ} \mathrm{C}$. The extraction time was $1 \mathrm{~h}$. After cooling, the samples were filtered and centrifuged for $5 \mathrm{~min}$ at $1800 \times g$. The extraction of each sample was performed in triplicate. The obtained extracts of the same plant species were combined into the final extract that was used in further experiments.

\section{Collection of human digestive juices}

Human gastric and duodenal juices were collected from four donors (two male and two female) without known gastrointestinal pathology, and who were not taking acid secretion inhibitors or antibiotics. Gastric and duodenal juices were aspirated through the endoscope. Eight hours before the procedure, all liquid or food intake was ceased. For each patient, $3 \mathrm{~mL}$ of initially aspired juice were discarded and the remaining amount was collected in a sterile tube, which was centrifuged to remove mucus and cell debris. In order to reduce interindividual variations, batches of pooled gastric and intestinal juices were prepared and then stored at $-20{ }^{\circ} \mathrm{C}$ until use. The approval for the collection of digestive juices was obtained from the Ethics Committee of the University Hospital Centre Split, Croatia.

\section{Determination of enzymatic activity of collected juices}

The procedure described by Almaas et al. (23) was used to determine enzymatic activity of the prepared pooled human gastric juice samples. Pepsin activity was measured using $2.5 \%$ solution of bovine haemoglobin. The solution was prepared in $0.2 \mathrm{M}$ phosphate buffer $(\mathrm{pH}=7.6)$ and then acidified (to $\mathrm{pH}=3$ ) using $\mathrm{H}_{2} \mathrm{SO}_{4}$. In order to determine the human duodenal juice activity, casein solution $(1 \%)$ dissolved in $0.2 \mathrm{M}$ phosphate buffer ( $\mathrm{pH}=7.6)$ was used. A volume of $500 \mu \mathrm{L}$ of prepared protein solutions was incubated with 5,20 or $50 \mu \mathrm{L}$ of gastrointestinal juice. The digestion reactions were stopped with the addition of $1 \mathrm{~mL}$ of $10 \%$ trichloroacetic acid (TCA). Samples were measured spectrophotometrically at $280 \mathrm{~nm}$. One unit (U) of enzyme activity is defined as the amount of enzyme that causes the absorbance change of 1 between the blank and the sample, after $20 \mathrm{~min}$ at $37^{\circ} \mathrm{C}$.

\section{In vitro digestion process}

A two-phase digestion procedure was performed according to the method described by Furlund et al. (24). Gastric and intestinal digestion phases were performed at $37^{\circ} \mathrm{C}$, in shaking bath (180 rpm). The volume of digestive juice corresponding to $1 \mathrm{U}$ of enzymatic activity was 20 $\mu \mathrm{L}$ of human gastric juice and $25 \mu \mathrm{L}$ of human duodenal juice. Before in vitro digestion procedure, the concentration of rosmarinic acid in the prepared aqueous extracts from selected plants was normalized $(471.48 \mathrm{mg} / \mathrm{L})$. For digestion, $4 \mathrm{~mL}$ of aqueous extracts were used. The $\mathrm{pH}$ of the samples was adjusted to $\mathrm{pH}=2.5$ using $1 \mathrm{M} \mathrm{HCl}$ for gastric phase, and to $\mathrm{pH}=7.5$ using $2 \mathrm{M} \mathrm{NaOH}$ for intestinal phase. The concentration of human juices used for this assay was $20 \mathrm{U}$ per $\mathrm{g}$ of plant material for gastric and $62.4 \mathrm{U}$ per $\mathrm{g}$ of plant material for intestinal phase. In order to determine the influence of different concentrations of juices on the stability of rosmarinic acid, following concentrations were used: 5,10 , and $20 \mathrm{U}$ per g of plant material for gastric phase, and 15.6, 20, and $62.4 \mathrm{U}$ per $\mathrm{g}$ of plant material for intestinal phase. The incubation period of gastric phase was $30 \mathrm{~min}$, while aliquots of intestinal samples were collected after 60 and 120 min of intestinal phase. Enzymatic reactions were stopped on ice and the samples were stored at $-20{ }^{\circ} \mathrm{C}$ until analyses. All digestion processes were run in duplicate. Stability rate of rosmarinic acid represents the ratio of its concentration before in vitro digestion and after gastric or intestinal digestion phases.

\section{HPLC-DAD detection of rosmarinic acid}

The rosmarinic acid was analyzed by a direct injection of the extracts, previously filtered through a $0.45-\mu \mathrm{m}$ pore size membrane filter (Macherey-Nagel GmbH \& Co. KG, Düren, Germany). Chromatographic separation was performed using HPLC instrument with Agilent 1260 quaternary LC Infinity system (Agilent Technologies, Santa Clara, CA, USA) equipped with diode array detector 
(DAD), an automatic injector and ChemStation software. The separation of compounds was performed on a Nucleosil 100-5C18 (250 mm×4.6 mm, i.d. $5 \mu \mathrm{m})$ column (Macherey-Nagel GmbH \& Co. KG). The solvent composition and the used gradient conditions were described previously by Generalić Mekinić et al. (13). For gradient elution, mobile phase A contained $2 \%$ of acetic acid (T.T.T., Sveta Nedelja, Croatia) in water, while solution B contained $2 \%$ of acetic acid in acetonitrile (BDH Prolabo, VWR International, Lutterworth, UK). The used elution program was as follows: from 0 to $3 \mathrm{~min} 2 \% \mathrm{~B}$, from 3 to $25 \mathrm{~min} 30 \% \mathrm{~B}$, from 25 to $35 \mathrm{~min} 80 \% \mathrm{~B}$, and finally for the last $5 \mathrm{~min}$ again $0 \% \mathrm{~B}$. The flow rate was $1.0 \mathrm{~mL} / \mathrm{min}$ and the injection volume was $24 \mu \mathrm{L}$. Detection was performed with UV/Vis-photo diode array detector (Agilent Technologies) by scanning from 250 to $300 \mathrm{~nm}$. Identification of rosmarinic was carried out by comparing retention times and spectral data with those of the authentic standards at $280 \mathrm{~nm}$. The quantifications of rosmarinic acid were made by the external standard method. Working rosmarinic acid standard solutions were prepared by diluting the stock solution to yield five concentrations in a range from 175 to $700 \mathrm{mg} / \mathrm{L}$. Quantitative determination was carried out using the calibration curves of the standard $\left(y=31.834 x, R^{2}=0.99\right)$. Quantitative determination was based on peak area from HPLC analyses and from the mass concentration of the compound. The results were expressed in $\mathrm{mg}$ per $\mathrm{mL}$ of extract, as mean value \pm standard deviation ( $N=2$ replicates).

\section{Statistical analysis}

Statistical analysis was performed using GraphPad InStat3 software (GraphPad Software Inc., San Diego, CA, USA). The relationship between the obtained parameters was described using Pearson's correlation coefficient $r$. Differences at $\mathrm{p}<0.05$ were considered to be statistically significant.

\section{Results and Discussion}

Lamiaceae species are known as a rich source of rosmarinic acid (14-16). In this study, three different plants from the Lamiaceae family were used: Thymus vulgaris L., Origanum majorana L. and Satureja montana L. Prepared aqueous extracts contained different concentrations of rosmarinic acid, measured by HPLC-DAD (Fig. 1). Therefore, before the two-step in vitro digestion, the concentration of rosmarinic acid was normalized in all prepared aqueous extracts so that the concentration measured in thyme $(471.48 \mathrm{mg} / \mathrm{L})$ was taken as primary concentration before in vitro digestion. Table 1 shows the concentration and the stability rate of rosmarinic acid in plant extracts in comparison with pure rosmarinic acid after the gastric digestion phase $(\mathrm{pH}=2.5)$. The duration of gastric phase was 30 min because liquids with a low protein concentration are considered to have very short transit time in the stomach (25). Rosmarinic acid was the most stable in Origanum majorana L. extract $(14.10 \%)$ in comparison with Satureja montana L. extract $(5.8 \%)$ and Thymus vulgaris L. extract $(0.8 \%)$ after digestion phase. However, the stability rate of pure rosmarinic acid was significantly higher (30.77\%) than in rosmarinic acid from plant mate- rial. Incubation temperature $\left(37^{\circ} \mathrm{C}\right)$ did not affect the stability of rosmarinic acid, which is in accordance with the results of other authors $(26,27)$. On the other hand, the incubation period of $30 \mathrm{~min}$ in the acidic medium $(\mathrm{pH}=2.5)$ decreased its concentration by more than $50 \%$ (Table 1 ). The obtained results are not in accordance with those presented by Dinis et al. (28), who concluded that rosmarinic acid in Mentha species was stable at low $\mathrm{pH}$ under simulated gastrointestinal conditions using commercial enzymes (pepsin and pancreatin). Contrary to commercial enzymes, human digestive juices consist of a variety of enzymes, inhibitors and bile salts that collectively contribute to the digestion of food sample (29). In human gastric juices the following components have been detected: pepsin, trypsin, gastricsin, bile, small peptides and protein fragments (30). Duodenal juice contains pancreatic and intestinal enzymes such as proteolytic enzymes, intestinal lipases, enterokinase, trypsinogen, chymotrypsinogen, and amylase (31).

Results of the stability determination of rosmarinic acid after intestinal digestion phase are shown in Table 1. Aliquots of digested samples were collected after 60 and $120 \mathrm{~min}$ of intestinal phase. Duration time of $120 \mathrm{~min}$ for intestinal phase was chosen according to in vivo results obtained by Troost et al. (32). The stability after intestinal digestion phase of pure rosmarinic acid differs completely from the stability of rosmarinic acid in plant extracts (Table 1). In comparison with its primary concentration in plant extracts, rosmarinic acid was almost completely degraded after intestinal digestion phase. After $120 \mathrm{~min}$ of intestinal digestion, the highest concentration was detected in Origanum majorana L. extract $(30.8 \mathrm{mg} / \mathrm{L})$. The obtained results are not in line with the results by Dinis et al. (28), who reported that pancreatin (commercial mixture of amylase, lipase and protease) did not provoke the degradation of rosmarinic acid in Mentha species. Also, Bel-Rhild et al. (33) did not observe any hydrolysis of rosmarinic acid after the passage of rosemary extract through the gastrointestinal tract model (using commercial digestive enzymes). Putative reasons for such discrepancies could be explained by two factors: the difference in in vitro digestion procedure between commercial digestive enzymes and human gastrointestinal enzymes, and the matrix effect - the rosmarinic acid can behave differently in Mentha species and/or Rosmarinus officinalis extract in comparison with other plant species containing it. In contrast to rosmarinic acid in aqueous plant extracts, pure rosmarinic acid showed very high resistance to digestion by intestinal human juices (its stability rate was approx. $78 \%$ after $120 \mathrm{~min}$ of intestinal phase). In addition, according to the results presented in Table 1, the degradation of rosmarinic acid after intestinal phase is not influenced by the $\mathrm{pH}$. At $\mathrm{pH}=7.5$ the rosmarinic acid is almost completely stable. Table 2 shows the influence of different concentrations of human gastric and duodenal juices on the stability of rosmarinic acid in the prepared aqueous extract from Satureja montana L. In order to investigate the influence of the concentration of human gastrointestinal juices, three different concentrations were tested: 5, 10 and $20 \mathrm{U}$ per $\mathrm{g}$ of plant material of gastric juices, and 15.6, 20 and $62.4 \mathrm{U}$ per $\mathrm{g}$ of plant material of duodenal juices. The obtained results showed that rosmarinic acid stability 


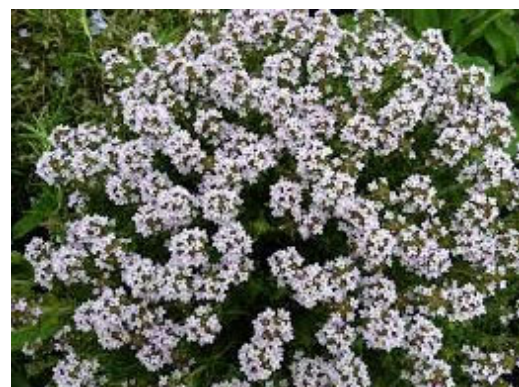

Thymus vulgaris $\mathrm{L}$.

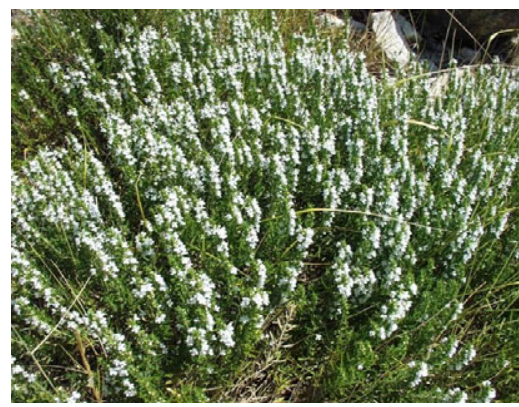

Satureja montana L.

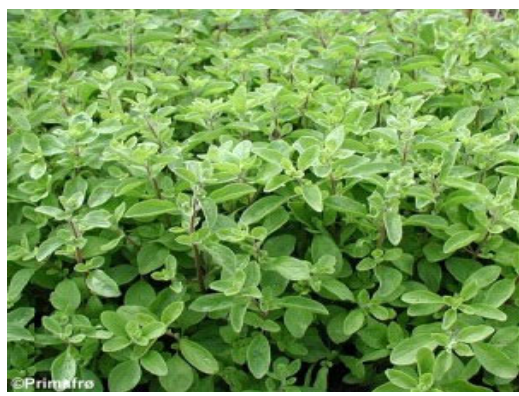

Origanum majorana L.
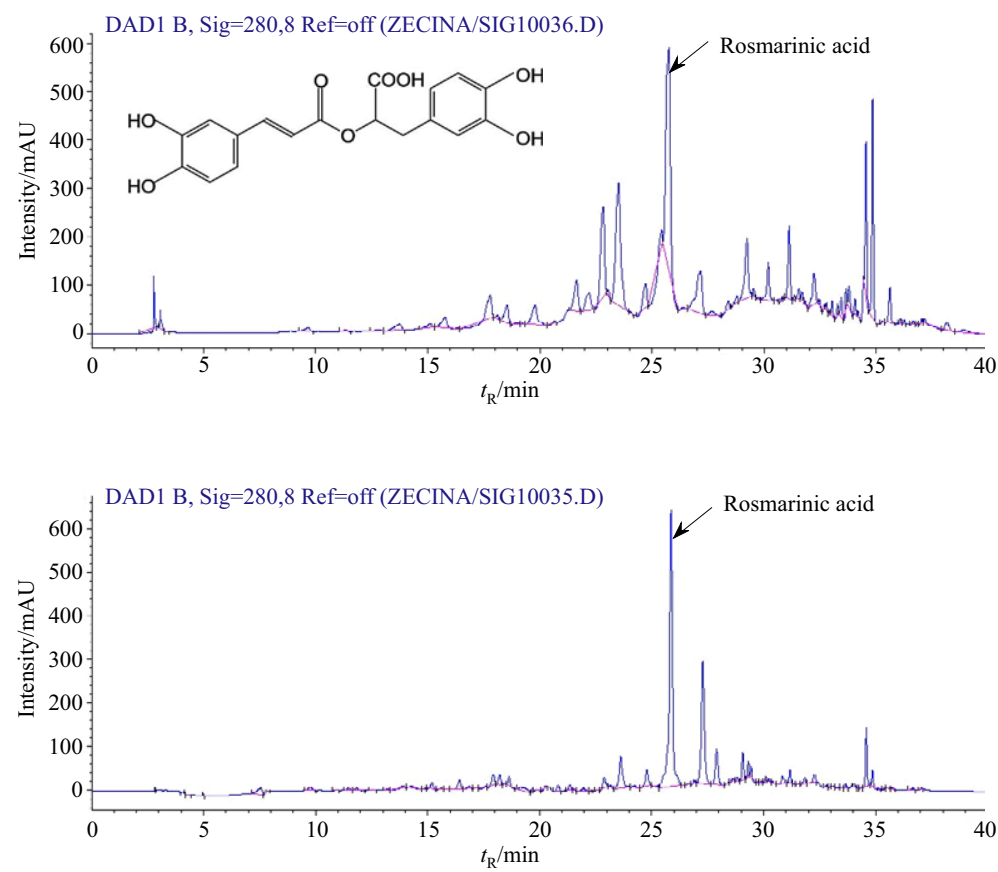

$\mathrm{CH}_{4}$

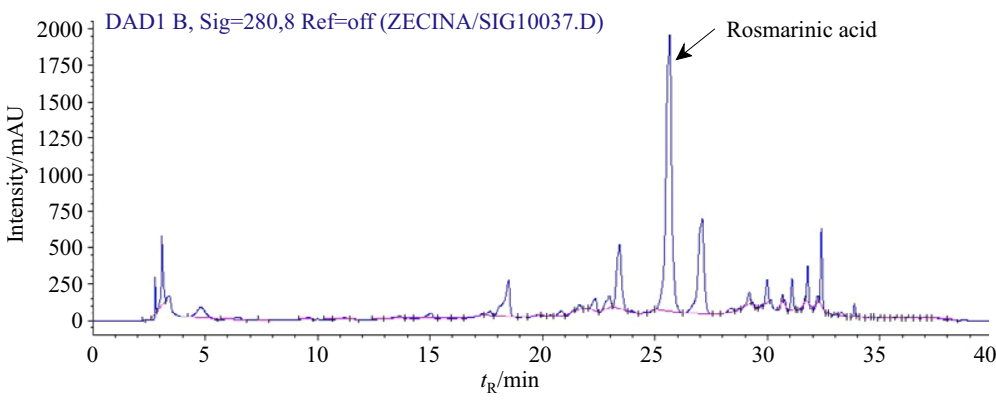

Fig. 1. The investigated Lamiaceae species and their HPLC-DAD chromatograms with the signed peak of the dominant compound (rosmarinic acid) and its structure. The rosmarinic acid concentration in Satureja montana L., Origanum majorana L. and Thymus vulgaris L. extracts was 1579.56, 821.06 and $471.48 \mathrm{mg} / \mathrm{L}$, respectively. Photos taken from Wikimedia Commons database

Table 1. Concentrations and stability rates of rosmarinic acid in aqueous extracts of Thymus vulgaris L., Satureja montana L. and Origanum majorana L. after in vitro gastric and intestinal digestion

\begin{tabular}{|c|c|c|c|c|c|c|}
\hline \multirow{3}{*}{ Sample } & \multirow{2}{*}{\multicolumn{2}{|c|}{$\begin{array}{c}\text { Gastric digestion } \\
t=30 \mathrm{~min}\end{array}$}} & \multicolumn{4}{|c|}{ Intestinal digestion } \\
\hline & & & \multicolumn{2}{|c|}{$t=60 \mathrm{~min}$} & \multicolumn{2}{|c|}{$t=120 \mathrm{~min}$} \\
\hline & $\gamma /(\mathrm{mg} / \mathrm{L})$ & Stability/\% & $\gamma /(\mathrm{mg} / \mathrm{L})$ & Stability/\% & $\gamma /(\mathrm{mg} / \mathrm{L})$ & Stability $/ \%$ \\
\hline Thymus vulgaris & $3.99 \pm 0.03$ & $0.8 \pm 0.0$ & $20.4 \pm 1.8$ & $4.3 \pm 0.3$ & $2.32 \pm 0.07$ & $0.49 \pm 0.01$ \\
\hline Satureja montana & $27.5 \pm 0.0$ & $5.8 \pm 0.0$ & $17.7 \pm 0.2$ & $3.75 \pm 0.03$ & $15.9 \pm 0.2$ & $3.81 \pm 0.05$ \\
\hline Origanum majorana & $66.5 \pm 0.2$ & $14.10 \pm 0.02$ & $29.10 \pm 0.09$ & $6.17 \pm 0.01$ & $30.8 \pm 4.2$ & $6.5 \pm 0.6$ \\
\hline Rosmarinic acid (control) & $145.1 \pm 0.4$ & $30.77 \pm 0.06$ & $463.3 \pm 0.1$ & $98.26 \pm 0.03$ & $370.8 \pm 0.2$ & $78.64 \pm 0.03$ \\
\hline Rosmarinic acid (undigested) & $(206.6 \pm 28.1)^{*}$ & $(43.81 \pm 0.03)^{*}$ & n.d. & n.d. & $(430.9 \pm 1.3)^{* *}$ & $(91.4 \pm 0.2)^{* *}$ \\
\hline
\end{tabular}

*at $\mathrm{pH}=2.5$, **at $\mathrm{pH}=7.5 ; \mathrm{n} . \mathrm{d} .=$ not detected

Concentration of human gastric juice was $20 \mathrm{U}$ per g of plant material and of human duodendal juice $62.4 \mathrm{U}$ per $\mathrm{g}$ of plant material. Results are expressed as mean value \pm standard deviation. The initial concentration of rosmarinic acid was $471.48 \mathrm{mg} / \mathrm{L}$ in all samples (including control)

depends on the concentration of human gastrointestinal juices (the lowest the concentration of digestive juice, the highest the stability of rosmarinic acid; Table 2).
Higher stability rate of rosmarinic acid after in vitro intestinal digestive phase may be also related to its ability to react with pancreatic enzymes that inhibit their activity 
Table 2. Concentrations and stability rates of rosmarinic acid in aqueous extract of Satureja montana L. after in vitro gastric and intestinal digestion in relation to different concentrations ( $U$ per $g$ of plant material) of human gastric juices (HGJ) and human intestinal duodenal juices (HDJ)

\begin{tabular}{|c|c|c|c|c|}
\hline \multirow{2}{*}{$\mathrm{HGJ} /(\mathrm{U} / \mathrm{g})$} & \multicolumn{4}{|c|}{$t=30 \mathrm{~min}$} \\
\hline & \multicolumn{2}{|c|}{$\gamma /(\mathrm{mg} / \mathrm{L})$} & \multicolumn{2}{|c|}{ Stability/\% } \\
\hline 5 & \multicolumn{2}{|c|}{$96.9 \pm 1.6$} & \multicolumn{2}{|c|}{$20.6 \pm 0.2$} \\
\hline 10 & \multicolumn{2}{|c|}{$80.1 \pm 0.2$} & \multicolumn{2}{|c|}{$16.99 \pm 0.03$} \\
\hline 20 & \multicolumn{2}{|c|}{$27.5 \pm 0.0$} & \multicolumn{2}{|c|}{$5.8 \pm 0.0$} \\
\hline \multirow{2}{*}{$\mathrm{HDJ} /(\mathrm{U} / \mathrm{g})$} & \multicolumn{2}{|c|}{$t=60 \mathrm{~min}$} & \multicolumn{2}{|c|}{$t=120 \mathrm{~min}$} \\
\hline & $\gamma /(\mathrm{mg} / \mathrm{L})$ & Stability/\% & $\gamma /(\mathrm{mg} / \mathrm{L})$ & Stability/\% \\
\hline 15.6 & $48.3 \pm 0.5$ & $10.24 \pm 0.07$ & $81.47 \pm 0.05$ & $17.3 \pm 0.0$ \\
\hline 20.0 & $25.8 \pm 0.2$ & $5.46 \pm 0.03$ & $36.65 \pm 0.05$ & $7.61 \pm 0.01$ \\
\hline 62.4 & $17.7 \pm 0.2$ & $3.75 \pm 0.03$ & $34.5 \pm 0.2$ & $3.81 \pm 0.05$ \\
\hline
\end{tabular}

The concentration of rosmarinic acid in undigested aqueous extract was $471.48 \mathrm{mg} / \mathrm{L}$. Results are expressed as mean value \pm standard deviation

(34). It was reported that rosmarinic acid-derived quinones react with amino acid side chains and free thiol groups of the enzyme (35). In addition, the interaction between phenolic acids and flavonoids has been reported and the presence of some flavonoids such as luteolin and apigenin enhances the stability rate of rosmarinic acid $(36,37)$. According to the available data, the highest content of luteolin and apigenin among the three selected Lamiaceae plants was detected in Origanum majorana aqueous extracts, in which the rosmarinic acid stability was the highest after both, gastric and intestinal phases (38).

\section{Conclusions}

There is a lack of information about the gastrointestinal stability of rosmarinic acid. Results of this study showed several interesting observations on digestive stability of rosmarinic acid using in vitro digestion with human gastrointestinal enzymes. The huge difference was found in the stability of pure rosmarinic acid and rosmarinic acid in aqueous extracts from different plant material belonging to Lamiaceae family. Pure rosmarinic acid was more stable after duodenal phase $(78.64 \%)$ than during gastric phase $(30.77 \%)$. Acid medium greatly reduced the stability of rosmarinic acid ( $>50 \%)$, while the effect of the incubation temperature and slightly alkaline medium were not significant. There were differences in the stability of rosmarinic acid among different plant extracts. In our study, rosmarinic acid showed the highest stability after both digestive phases in Origanum majorana aqueous extract. In addition, the concentration of human gastrointestinal juices affected the stability of rosmarinic acid in both digestive phases. Finally, the obtained results showed lower gastrointestinal stability of rosmarinic acid than in other studies using commercial digestive enzymes.

\section{Acknowledgements}

The authors wish to thank Dr. Ivica Blažević, Assistant Professor at the Faculty of Chemistry and Technolo- gy, Department of Organic Chemistry, Split, Croatia, for valuable comments.

\section{References}

1. Zhang $Y$, Li X, Wang Z. Antioxidant activities of leaf extract of Salvia miltiorrhiza Bunge and related phenolic constituents. Food Chem Toxicol. 2010;48:2656-62. http://dx.doi.org/10.1016/j.fct.2010.06.036

2. Chu X, Ci X, He J, Jiang L, Wei M, Cao Q, et al. Effects of a natural propyl oligopeptidase inhibitor, rosmarinic acid, on lipopolysaccharide-induced acute lung injury in mice. Molecules. 2012;17:3586-98. http://dx.doi.org/10.3390/molecules17033586

3. Furtado MA, de Almeida LCF, Furtado RA, Cunha WR, Tavares DC. Antimutagenicity of rosmarinic acid in Swiss mice evaluated by the micronucleus assay. Mutat Res-Gen Tox En. 2008;57:150-4. http://dx.doi.org/10.1016/j.mrgentox.2008.09.003

4. Moreno S, Scheyer T, Romano CS, Vojnov AA. Antioxidant and antimicrobial activities of rosemary extracts linked to their polyphenol composition. Free Radic Res. 2006;40:223-31. http://dx.doi.org/10.1080/10715760500473834

5. Swarup V, Ghosh J, Ghosh S, Saxena A, Basu A. Antiviral and anti-inflammatory effects of rosmarinic acid in an experimental murine model of Japanese encephalitis. Antimicrob Agents Chemother. 2007;51:3367-70. http://dx.doi.org/10.1128/AAC.00041-07

6. Berdowska I, Zielihski B, Fecka I, Kulbacka J, Saczko J, Gamian A. Cytotoxic impact of phenolics from Lamiaceae species on human breast cancer cells. Food Chem. 2013;15:1313-21. http://dx.doi.org/10.1016/j.foodchem.2013.03.090

7. Braidy N, Matin A, Rossi F, Chinain M, Laurent D, Guillemin GJ. Neuroprotective effects of rosmarinic acid on ciguatoxin in primary human neurons. Neurotox Res. 2014;25:22634

http://dx.doi.org/10.1007/s12640-013-9429-9

8. Domitrović R, Potočnjak I, Crnčević-Orlić Ž, Škoda M. Nephroprotective activities of rosmarinic acid against cisplatininduced kidney injury in mice. Food Chem Toxicol. 2014;66: 321-8.

http://dx.doi.org/10.1016/j.fct.2014.02.002

9. Ellis BE, Towers GHN. Biogenesis of rosmarinic acid in Mentha. Biochem J. 1970;118:291-7. http://dx.doi.org/PMC1179116

10. Scarpati ML, Oriente G. Isolation and composition of rosmarinic acid (from Rosmarinus off.). Ricerca Sci. 1958;28:2329_ 33 (in Italian).

11. Petersen M, Abdullah Y, Benner J, Eberle D, Gehlen K, Hücherig $S$, et al. Evolution of rosmarinic acid and biosynthesis. Phytochemistry. 2009;70:1663-79. http://dx.doi.org/10.1016/j.phytochem.2009.05.010

12. Petersen M, Simmonds MSJ. Rosmarinic acid. Phytochemistry. 2003;62:121-5. http://dx.doi.org/10.1016/S0031-9422(02)00513-7

13. Generalić Mekinić I, Burčul F, Blažević I, Skroza D, Kerum D, Katalinić V. Antioxidative/acetylcholinesterase inhibitory activity of some Asteraceae plants. Nat Prod Commun. 2013;8:471-4.

14. Sellami IH, Maamouri E, Chahed T, Wanes WA, Kchouk ME, Marzouk B. Effect of the growth stage on the content and composition of the essential oil and phenolic fraction of sweet marjoram (Origanum majorana L.). Ind Crop Prod. 2009;30:395-402. http://dx.doi.org/10.1016/j.indcrop.2009.07.010

15. Hossain MB, Rai DK, Brunton NP, Martin-Diana AB, Barry-Ryan C. Characterization of phenolic composition in Lamia- 
ceae species by LC-ESI-MS/MS. J Agric Food Chem. 2010;58: 10576-81. http://dx.doi.org/10.1021/jf102042g

16. Vladimir-Knežević S, Blažeković B, Kindl M, Vladić J, Lower-Nedza AD, Brantner AH. Acetylcholinesterase inhibitory, antioxidant and phytochemical properties of selected medicinal plants of the Lamiaceae family. Molecules. 2014;19: 767-82.

http://dx.doi.org/10.3390/molecules19010767

17. Öztürk M, Duru ME, İnce B, Harmadar M, Topçu G. A new rapid spectrophotometric method to determine the rosmarinic acid level in plant extracts. Food Chem. 2010;123:1352-6. http://dx.doi.org/10.1016/j.foodchem.2010.06.021

18. Ondrejovič M, Maliar T, Benkovičová H, Kubincová J. Solid-phase extraction for photometric determination of rosmarinic acid in lemon balm (Melissa officinalis) extracts. Nova Biotechnol Chim. 2012;11:63-71.

http://dx.doi.org/10.2478/v10296-012-0007-y

19. Luis JC, Johnson CB. Seasonal variations of rosmarinic and carnosic acids in rosemary extracts. Analysis of their in vitro antiradical activity. Span J Agric Res. 2005;3:106-12. http://dx.doi.org/10.5424/sjar/2005031-130

20. Del Baño MJ, Castillo J, Benavente-García O, Lorente J, Martín-Gil R, Acevedo C, Alcaraz M. Radioprotective-antimutagenic effects of rosemary phenolics against chromosomal damage induced in human lymphocytes by $\gamma$-rays. J Agric Food Chem. 2006;54:2064-8. http://dx.doi.org/10.1021/jf0581574

21. Azevedo MF, Lima CF, Fernandez-Ferreira M, Almeida MJ, Wilson JM, Pereira-Wilson C. Rosmarinic acid, major phenolic constituent of Greek sage herbal tea, modulates rat intestinal SGLT1 levels with effects on blood glucose. Mol Nutr Food Res. 2011;55:S15-25. http://dx.doi.org/10.1002/mnfr.201000472

22. Granado F, Olmedilla B, Herrero C, Pérez-Sacristán B, Blanco I, Blásquez S. Bioavailability of carotenoids and tocopherols from broccoli: in vivo and in vitro assessment. Exp Biol Med (Maywood). 2006;231:1733-8.

23. Almaas H, Cases AL, Devold TG, Holm H, Langsrud T, Aabakken $\mathrm{L}$, et al. In vitro digestion of bovine and caprine milk by human gastric and duodenal enzymes. Int Dairy J. 2006; 16:961-8.

http://dx.doi.org/10.1016/j.idairyj.2005.10.029

24. Furlund CB, Kristoffersen AB, Devold TG, Vegarud GE, Jonassen $C M$. Bovine lactoferrin digested with human gastrointestinal enzymes inhibits replication of human echovirus 5 in cell culture. Nutr Res. 2012;32:503-13. http://dx.doi.org/10.1016/j.nutres.2012.06.006

25. Lin HC, Prather C, Fisher RS, Meyer JH, Summers RW, Pimentel $\mathrm{M}$, et al. Measurement of gastrointestinal transit. Dig Dis Sci. 2005;50:989-1004.

http://dx.doi.org/10.1007/s10620-005-2694-6

26. Fletcher RS, Slimmon T, McAuley CY, Kott LS. Heat stress reduces the accumulation or rosmarinic acid and the total antioxidant capacity in spearmint (Mentha spicata L.). J Sci
Food Agric. 2005;85:2429-36.

http://dx.doi.org/10.1002/jsfa.2270

27. Erkan N. Stability of some phenolic antioxidants and linoleic acid in solution under microwave and conventional heating conditions. Focus Modern Food Ind. 2013;2:179-84.

28. Dinis PC, Falé PL, Amorim Madeira PJ, Florêncio MH, Serralheiro ML. Acetylcholinesterase inhibition activity after in vitro gastrointestinal digestion of infusions of Mentha species. Eur J Med Plant. 2013;3:381-93. http://dx.doi.org/10.9734/EJMP/2013/3430

29. Eriksen EK, Holm H, Jensen E, Aaboe R, Devold TG, Jacobsen $M$, Vegarud GE. Different digestion of caprine whey proteins by human and porcine gastrointestinal enzymes. $\mathrm{Br} \mathrm{J}$ Nutr. 2010:104:374-81. http://dx.doi.org/10.1017/S0007114510000577

30. Foltz E, Azad S, Everett ML, Holzknecht ZE, Sanders NL, Thompson JW, et al. An assessment of human gastric fluid composition as a function of PPI usage. Physiol Rep. 2015;3: e12269. http://dx.doi.org/10.14814/phy2.12269

31. Hur SJ, Lim BO, Decker EA, McClements DJ. In vitro human digestion models for food applications. Food Chem. 2011;125: $1-12$. http://dx.doi.org/10.1016/j.foodchem.2010.08.036

32. Troost FJ, Steijns J, Saris WHM, Brummer RJM. Gastric digestion of bovine lactoferrin in vivo in adults. J Nutr. 2001; 131:2101-4.

33. Bel-Rhild R, Crespy V, Pagé-Zoerkler N, Nagy K, Raab T, Hansen CE. Hydrolysis of rosmarinic acid from rosemary extract with esterases and Lactobacillus johnsonii in vitro and in a gastrointestinal model. J Agric Food Chem. 2009;57: $7700-5$. http://dx.doi.org/10.1021/jf9014262

34. McCue PP, Shetty K. Inhibitory effects of rosmarinic acid extracts on porcine pancreatic amylase in vitro. Asia Pacific J Clin Nutr. 2004;13:101-6.

35. Rhon S, Rawel HM, Kroll J. Inhibitory effects of plant phenols on the activity of selected enzymes. J Agric Food Chem. 2002;50:3566-71.

http://dx.doi.org/10.1021/jf011714b

36. Konishi K, Kobayashi S, Shimizu M. Tea polyphenols inhibit the transport of dietary phenolic acids mediated by the monocarboxylic acid transporter (MCT) in intestinal Caco-2 cell monolayers. J Agric Food Chem. 2003;51:7296-302. http://dx.doi.org/10.1021/jf034894t

37. Falé PL, Ascensão L, Serralheiro MLM. Effect of luteolin and apigenin on rosmarinic acid bioavailability in Caco-2 cell monolayers. Food Funct. 2013;4:426-31. http://dx.doi.org/10.1039/C2FO30318C

38. Roby MHH, Sarhan MA, Selim KAH, Khalel KI. Evaluation of antioxidant activity, total phenols and phenolic compounds in thyme (Thymus vulgaris L.), sage (Salvia officinalis L.), and marjoram (Origanum majorana L.) extracts. Ind Crop Prod. 2013;43:827-31. http://dx.doi.org/10.1016/j.indcrop.2012.08.029 